\title{
Mundos entrecruzados: Formação de professores leigos*
}

(Dulce Maria Pompêo de Camargo)

Doraci Alves Lopes**

A primeira idéia que me ocorreu ao me propor a escrever esta resenha foi a de que seria muito difícil me aventurar a pensar o livro "Mundos entrecruzados", apenas com base na docência de Ciências Sociais no ensino superior. Pensei, ao mesmo tempo, que seria gratificante a tarefa de transmitir alguma reflexão até certo ponto "estrangeira", de alguém que observa a distância e com entusiasmo a experiência do Projeto Inajá ${ }^{-}$- Curso de formação e habilitação de professores leigos em exercício do Magistério, MT (1987-1990).

Em 1990, ao visitar Santa Terezinha do Araguaia, município sede do Projeto, tive a oportunidade de dimensionar a riqueza da troca de conhecimentos que estava ocorrendo em modestas salas de aulas, literalmente à beira do rio, um cenário natural fantástico reunindo pessoas com modos de vida tão diferentes entre si, alunos e professores.

Esses professores leigos vieram da roça, da cidade, dos patrimônios (distritos de municípios) e da aldeia Tapirapé e agora, após o Inajá ...., possuem habilitação em nível de $2^{\circ}$ grau. A grande maioria é constituída de posseiros que complementam o orçamento doméstico como professores. (...) vivem isolados, precariamente servidos pelos meios de comunicação e de transporte e que, ao longo do curso, ao buscarem a recuperação de sua identidade, começaram a perceber o valor de sua história, (...). Enfim, essa experiência singular, ainda hoje ausente da História da Educação Brasileira, precisava, urgentemente, ser relatada, sistematizada e

\footnotetext{
* Campinas: Ed. Alínea, 1997.

** Departamento de Ciências Sociais, Instituto de Ciências Humanas, PUC-Campinas.
} 
refletida (...). Essa é, portanto, a principal preocupação e objeto deste trabalho, cuja importância está diretamente relacionada ao despontar de novos projetos no Brasil em tempos e espaços diferentes. (Camargo 1997, pp. 13, 14)

Entre muitas, a questão que mais me entusiasmou para escrever sobre o livro foi a riqueza de abordagens e discussões possíveis de serem feitas com base na análise da professora Dulce M.P. de Camargo. Flagrei-me perguntando qual delas seria a mais importante para demonstrar a relevância de sua interpretação acadêmica. Relendo o livro, admito que essa é uma falsa questão.

Poderão se reconhecer nesse complexo universo de vivências culturais e educacionais, desenvolvidas no Médio Araguaia, para mencionar apenas algumas delas, muitos perfis de leitores, principalmente aqueles comprometidos com diferentes graus de ensino e áreas de conhecimento.

As múltiplas possibilidades de análise do Projeto Inajá devemse, evidentemente, a vários fatores conjugados ou oportunamente reunidos. Podemos perceber alguns, como a formação intelectual da autora, que trabalha com competência e sensibilidade áreas como as de educação, história, geografia, sociologia, metodologia da pesquisa social, metodologia da pesquisa em educação, compondo uma visão multi e interdisciplinar em seu caminho intelectual. A própria bibliografia chama a atenção, com distintas contribuições teóricas, permeadas por uma direção metodológica voltada, especialmente, para a etnografia.

Ao citar Elsie Rockwell, traduz o trabalho conjunto com outros professores do Projeto Inajá, das áreas de história, geografia e sociologia.

Pelo seu posicionamento, a autora não se coloca nem entre os empiristas radicais nem entre os racionalistas. Sua posição é a de que é possível ter uma outra forma de conceber a relação teoria e pesquisa. (...) Assim, a descrição do particular é a conseqüência da elaboração teórica e não somente da observação empírica. Portanto, a experiência de campo não deve ocorrer em um vazio teórico. (...) Quanto ao Projeto, este visa sobretudo atingir a realidade escolar no contexto rural e indígena, a partir da observação e da experimentação. Nesta perspectiva, 
(...) rompe com o ensino convencional (...). Esta prática teve como estratégia principal o Laboratório Vivencial - ou seja, a vizinhança do observador que percebe essa realidade a partir de seus referenciais (...). Apesar de ser o mais "intercisciplinar" dos laboratórios, necessita de uma metodologia que permita a sistematização do conhecimento. Assim, tal metodologia teve como fundamentação básica a abordagem etnográfica para o tratamento do conteúdo observado. (Camargo 1997, pp. 32-34)

Outro argumento em favor de seu livro é a seriedade com que trata de explicar ao leitor os inúmeros e inusitados desafios teórico-metodológicos enfrentados na prática, dada a sua capacidade de trabalho coletivo, mergulhando em trocas contínuas de idéias com muitos dos educadores igualmente responsáveis pelo Projeto Inajá. Em companhia dos mesmos atuou seja como sujeito da construção teórica de um processo educacional único, seja como aprendiz dos Professores leigos, ou Cursistas, plenos de conhecimentos da vida local.

O senso de compromisso na condução desse projeto educacional emerge constantemente da leitura, uma vez que vamos sendo introduzidos na importância da história regional por intermédio de temas como terra e trabalho, ou descobrindo os conflitos e a diversidade cultural dos grupos sociais existentes, por meio dos conteúdos e sentidos que os Cursistas do Projeto Inajá vão dando a conceitos como espaço, tempo e relações sociais. Sistematizando o conhecimento empírico, até então política e socialmente disperso, fundamentalmente chegam a uma visão mais crítica e complexa do mundo, reelaborando suas respectivas histórias de vida ao passarem à condição de Professores, agora não mais leigos.

É interessante acompanhar, em muitos momentos do livro, como as reflexões sobre as práticas de ensino do grupo de professores do Projeto Inajá vão emergindo tanto do calor da hora das salas de aula no Araguaia, como dos trabalhos acadêmicos em Campinas.

Finalmente, como socióloga, preocupada com temas relacionados a movimentos sociais, habitação, modos de vida, história e cultura da classe trabalhadora no Brasil, destaco ainda outra contribuição da obra.

O Projeto Inajá emergiu de aspirações de um movimento social com características acentuadamente políticas, em decorrência dos anos de ditadura, que foi se firmando como movimento social de tendências mais culturais, com transformações irreversíveis para o processo educa- 
cional das populações locais, porém, sem deixar de afetar ou mesmo contrariar velhos interesses políticos e econômicos, típicos da região.

Inajá! Realmente não poderia haver nome mais significativo para um Projeto que resistiu a tantas adversidades desde os primeiros minutos em que foi gestado. Sintetiza a história de 20 anos de lutas na região. (...) se originou de iniciativas educacionais isoladas, lideradas por um grupo de pessoas provenientes não só da região, como também do sul e sudeste do país. (...) Dentre os problemas principais, destacavam-se: a não distribuição equitativa das escolas do ponto de vista geográfico; a precária formação do professor; o elevado índice de analfabetismo; o grande número de crianças que permanecia fora da escola e a significativa evasão escolar. (Camargo 1997, pp. 17, 18)

Nos dois primeiros capítulos da obra, a autora contextualiza histórica e geograficamente o Projeto e a região do Médio Araguaia, onde este se desenvolve. Nos três últimos, aborda o processo de construção da metodologia, problematizando espaços e tempos diferentes, o que, ao final, possibilita ao leitor a compreensão do significado do título do livro: Mundos entrecruzados ...

Em tempos de nova LDB, esse livro é absolutamente atual, pois permite problematizações abertas para pensarmos diferentes caminhos ou novas vivências educacionais também nos grandes centros urbanos. Para mim, reafirma nosso objetivo primeiro, que é formar um aluno ético, um cidadão que deve se construir sujeito de conhecimento, numa perspectiva de capacitação permanente, continuada, para atuar no mundo em que vive. Desse modo, não perderemos de vista o compromisso coletivo maior para com o contínuo aperfeiçoamento democrático de nossa sociedade.

As sementes do Inajá foram espalhadas (...) o Médio Araguaia que, no início dessa experiência educacional, me parecia um "horizonte utópico", ao final dela, se transformou em "lugar epistemológico", conforme expressões de René Girard. Nele, pude, em co-autoria, desenvolver uma prática pedagógica que resultou na construção de uma metodologia de trabalho fundamentada na etnografia, na História Nova e na Geografia Crítica. (...) um caminho de reflexão a posteriori. Ele tem como base uma síntese de conhecimento que perpassa mais de 20 anos de leitura. (Camargo 1997, pp. 167-168) 
Reconhecer a diversidade e discutir o papel dos movimentos sociais na (re)construção do conhecimento que se opera no desenvolvimento do pensamento científico, e vice-versa, é um desafio ainda pouco perseguido pela academia. Nessa perspectiva, a leitura de Mundos entrecruzados foi gratificante, uma vez que os movimentos sociais não podem ser interpretados apenas conjuntural ou pontualmente, seja no tempo, seja no espaço social em que costumam deixar suas marcas e seus desdobramentos.

\section{Notas}

1 Palmeira da região do Médio Araguaia. que morre e volta a nascer, mesmo depois de queimadas. Resiste ao clima adverso, sem água, em tempo de seca. 